\title{
Effect of Larval Density of Helicoverpa armigera (Hubner) on Pod Damage and Yield of Chickpea
}

\author{
Vipin Kumar, K.C. Gupta, S.K. Jain, Nitin Chawla
}

10.18805/ag.D-5134

\begin{abstract}
Background: Chickpea (Cicer arietinum L.) is cultivated in almost all parts of world covering more than 50 countries spread over Asia, Africa Europe, Australia, North America and South America countries and is the second most important food legumes crop after common bean (Phaseolus vulgaris L.). Chickpea has played a major role in realization of pulse Revolution in india making the country near self-sufficient in pluses. Gram is extensively grow in india. Due to its high nutritional value and its ability to fix atmospheric nitrogen, its more widely cultivated rabi pulse crop. The gram pod borer Helicoverpa armigera (Hubner) is most important pest of chickpea. Many pesticides were so far tested against this pest but due to over use of these pesticides resistance, residue and resurgence problems arises, beside destruction of natural enemies.

Methods: To determination of per cent pod damage and yield of chickpea due to different larval density of $H$. armigera is an important tool to reduce the cost of cultivation by avoiding the unnecessary use of pesticides. Therefore, a pot experiment was conducted in arranged in a completed randomized design with four replications. The pots were placed under natural field conditions and take observation at Research farm, Rajasthan Agricultural Research Institute, Durgapura, Jaipur during 2015-16 and 2016-17.

Result: The results revealed that least per cent pod damage $(29.05,24.78 \%)$ was recorded when the larval population was one per plant, while the maximum pod damage (64.55 and 67.76\%) was recorded during 2015-16 and 2016-17, respectively. The simple liner correlation analysis indicated that there was a significant positive correlation ( $r=0.989$ and 0.999$)$ between the larval density and per cent pod damage. Further, a significant correlation was noticed between larval density and number of healthy pods per plant, reduction in yield, yield per plant, total number of pod and damaged pods were $-0.964,-0.976 ; 0.98,0.986 ;-0.98,-0.986 ; 0.117,0.126$ and; 0.985 and 0.992, respectively during 2015-16 and 2016-17.
\end{abstract}

Key words: Chickpea, Helicoverpa armigera (Hubner), Larval density, Pod borer.

\section{INTRODUCTION}

Pulses are important source of dietary protein and calories for vegetarian masses and are usually grown with minimum external input in mostly marginal and stress prone soil and environment condition. Pulses play an important role in supplying protein to the large population of country that consumes pulses for meeting its food and nutritional needs. Beside their role in amino acid balance when supplemented with cereal in human and animal diet, they are known as a potent source of energy, carbohydrate, fat phosphorus, calcium, magnesium, iron and zinc. Chickpea is the major crop with share of about $49 \%$ of the total pulses being produced in india. The crop is grown in almost every part of the country with an increasing trend in production and productivity in the recent years. There has been remarkable increase in chickpea production and productivity in country during 2014-15 to 2020-21. from a level of 7.59 million tones in 2014-15, chickpea production rose to an all time of 12.61 million tones during 2020-21. It is about increase $66 \%$ during last six years. Similarly, there is an increase of more than $26 \%$ in chickpea productivity during the period. (Anonymous 2021) India is the largest producer of chickpea with more than $2 / 3^{\text {rd }}$ share in area and production of chickpea in the world. MP, Rajasthan, Maharashtra, UP, AP, Karntaka, Chhattisgargh, Bihar and Jharkhand contribute more than $95 \%$ to the total chickpea production in the country. India is
Rajasthan Agriculture Research Institute, SKN Agriculture University, Durgapura-302 018, Jaipur, Rajasthan, India.

Corresponding Author: Vipin Kumar, AICRP on Chickpea, Rajasthan Agriculture Research Institute, SKN Agriculture University, Durgapura-302 018, Jaipur, Rajasthan, India.

Email: vipindoriya@rediffmail.com

How to cite this article: Kumar, V., Gupta, K.C., Jain, S.K. and Chawla, N. (2022). Effect of Larval Density of Helicoverpa armigera (Hubner) on Pod Damage and Yield of Chickpea. Agricultural Science Digest. 42(1): 76-79. DOI: 10.18805/ag.D-5134.

Submitted: 18-01-2020 Accepted: 21-04-2021 Online: 07-01-2022

the largest producer of chickpea with a share of about 70 per cent in area and 67 per cent in the production in the world. In Rajasthan chickpea is grown on about 2463.05 thousand ha. with the production of 2657.63 thousand tone and yield $1079 \mathrm{~kg} / \mathrm{ha}$. (Anonymous 2021) Among the various factors that limit the production of gram, damage cause by insect pest is very important. Gram pod borer $(H$. armigera) is the serious pest of chickpea, which may result yield loss from 10 to 60 per cent under field conditions (Vaishmpayan and Veda, 1980). For the effective control this pest, continuous use of pesticides has posed the problems of insect resistance and resurgence. Determination of economic threshold level $(E T L)$ is an important tool to reduce the cost 
of cultivation by avoiding the unnecessary use of pesticides. It is also basic concept of integrated pest management. Thus, keeping in view the present experiment was undertaken to select the determination of ETL level of $\mathrm{H}$. armigera infesting gram.

\section{MATERIALS AND METHODS}

\section{Determination of economic threshold level (ETLs)}

Laboratory culture of $H$. armigera was maintained as described earlier (Anonymous 1995). Sequential batches were maintained in the culture to get freshly emerged larvae coinciding with the post flowering stage of the potted plants.

\section{Preparation of potted plants}

Cement pot of $30 \mathrm{~cm}$ diameter and $30 \mathrm{~cm}$ height were used. They were filled with compost soil mixture (1:1), lightly irrigated and allowed to settle for two days before sowing. Sowing was done on the third week of October at the rate 34 seeds per pot. Altogether 25 pots were prepared and they were thinned to maintain a single plant per pot after establishment. The plants were given irrigation, hoeing and other cultural practices as per requirement.

Individual round cages of $0.5 \mathrm{~cm}$ width and $1.5 \mathrm{~m}$ height were prepared with while net on bamboo pegs fixed at soil level to protect them from natural infestation. Uniform 24 cages were selected and arranged in a completed randomized design with four replications. The pots were placed under natural field conditions.

\section{Application of treatment and observation}

To the individual healthy plants in the cage, emerged larvae of $H$. armigera were released on 24 caged plants at post flowering stage at evening hours when the plants were about
100 days old and larval population density of $0,1,2,3,4$ and 5 per plant was maintained. The pots were cage and each treatment was replicated four times. Before releasing, all plants were thoroughly examined to make these free from any pests.

The dead larvae if any were replaced by the larvae of the same age group from the laboratory culture. On completion of the larval period the cages were removed. At harvest, healthy and damaged pods were recorded. The grain yield was also recorded. The data thus obtained were subjected to statistical analysis.

\section{Determination of EIL}

The EIL was determined by the procedure suggested by Hammond and Pedigo (1982):

Grain threshold $(\mathrm{GT})=$

$$
\frac{\text { Management cost (Rs. } / \mathrm{ha})}{\text { Market value of grain (Rs. /ha) }}=\mathrm{kg} / \mathrm{ha}
$$

Economic injury level (EIL) $=$

$$
\frac{\text { Grain threshold }(\mathrm{kg} / \mathrm{ha})}{\text { Loss per insect }(\mathrm{kg} / \text { insect })}=\text { insects } / \mathrm{ha}
$$

Management cost was calculated based on prevailing market price of the insecticides and application cost, while the market value of grain was calculated from the whole sale value of gram at the local market around the harvesting time.

\section{Estimation of economic threshold level}

The method reported by Johnston and Bishop (1987) to estimate the economic threshold was adopted in the present investigation. They established that economic threshold level would be the population at EIL minus the increase in pest population per day. Thus in the present investigation, the

\begin{tabular}{|c|c|c|c|c|c|c|c|c|}
\hline \multirow{2}{*}{ Year } & \multirow{2}{*}{$\begin{array}{c}\text { Larval density } \\
\text { per plant }\end{array}$} & \multicolumn{4}{|c|}{ Number of pods/plant } & \multirow{2}{*}{$\begin{array}{c}\text { Yield/plant } \\
\text { (g) }\end{array}$} & \multirow{2}{*}{$\begin{array}{l}\text { Reduction } \\
\text { in yield ( } \mathrm{g} \text { ) }\end{array}$} & \multirow{2}{*}{$\begin{array}{c}\text { Yield loss } \\
\text { (\%) }\end{array}$} \\
\hline & & Total & Healthy & Damaged & $\%$ pod damaged & & & \\
\hline \multirow[t]{12}{*}{ Rabi 2015-16 } & 0.00 & 35.50 & 35.50 & 0.00 & 0.00 & 12.71 & 0.00 & 0.00 \\
\hline & & & & & & $(0.00)$ & & \\
\hline & 1.00 & 32.75 & 25.00 & 7.75 & 23.70 & 9.76 & 2.95 & 23.21 \\
\hline & & & & & & $(29.05)$ & & \\
\hline & 2.00 & 30.00 & 18.00 & 12.00 & 39.95 & 7.26 & 5.45 & 42.87 \\
\hline & & & & & & $(39.16)$ & & \\
\hline & 3.00 & 36.25 & 15.75 & 20.50 & 56.57 & 5.89 & 6.82 & 53.65 \\
\hline & & & & & & $(48.78)$ & & \\
\hline & 4.00 & 37.75 & 14.00 & 23.75 & 62.85 & 5.35 & 7.36 & 57.90 \\
\hline & & & & & & $(52.50)$ & & \\
\hline & 5.00 & 32.50 & 6.00 & 26.50 & 81.40 & 2.38 & 10.33 & 81.27 \\
\hline & & & & & & $(64.55)$ & & \\
\hline SEm \pm & - & 0.53 & 0.85 & 1.00 & 1.52 & 0.43 & 0.63 & - \\
\hline CD at $5 \%$ & - & 1.58 & 2.52 & 2.96 & 4.52 & 1.27 & 1.87 & - \\
\hline
\end{tabular}

Table 1: Effect of different levels of larval density of $H$. armigera on gram during rabi 2015-16.

*Mean of four replications. Figures in parentheses are retransformed percent value. 
increasing rate of larval population in the field was determined by recording the weekly population of $H$. armigera during larval activity. The rate of increase in population was calculated arithmetically.

ETL was estimated by deducting the increase in larval population per day from the respective ETLs.

\section{RESULTS AND DISCUSSION}

Results revealed that at one larvae density per plant, 29.05 , 24.78 per cent pods were damage during 2015-16 and 201617 , respectively and with the increase in larvae density per plant there was increase in damage pods. At 2, 3, 4 and 5 larval density per plant, the percentage of damaged pods on number basis were $39.16,48.78,52.50$ and 64.55 during
2015-16 (Table 1) while 36.45, 47.78, 56.32 and 67.76 per cent respectively during 2016-17 (Table 2). The simple liner co correction analysis indicated that there was a significant positive correlation ( $r=0.989$ and 0.999 ) between the larval density and per cent pod damage. Consequently, a significant correlation was obtained with larval density and number of healthy pods per plant reduction in yield, yield per plant, total number of pod and damaged pods were $-0.964,0.98$, $-0.98,0.117$ and $0.985 ;-0.976,0.986,-0.986$ and 0.16 during 2015-16 and 2016-17 respectively (Table 3,4 ).

The finding of present investigation is in agreement with the earlier work carried out by Odak and Thakar (1975) who reported that when four larvae of $H$. armigera per square meter in chickpea at flowering stage and pod formation stage

Table 2: Effect of different levels of larval density of $H$. armigera on gram during rabi 2016-17.

\begin{tabular}{|c|c|c|c|c|c|c|c|c|}
\hline \multirow{2}{*}{ Year } & \multirow{2}{*}{$\begin{array}{c}\text { Larval density } \\
\text { per plant }\end{array}$} & \multicolumn{4}{|c|}{ Number of pods/plant } & \multirow{2}{*}{$\begin{array}{c}\text { Yield/plant } \\
\text { (g) }\end{array}$} & \multirow{2}{*}{$\begin{array}{l}\text { Reduction } \\
\text { in yield (g) }\end{array}$} & \multirow{2}{*}{$\begin{array}{c}\text { Yield loss } \\
\qquad(\%)\end{array}$} \\
\hline & & Total & Healthy & Damaged & $\%$ pod damaged & & & \\
\hline \multirow[t]{12}{*}{ Rabi 2016-17 } & 0.00 & 37.50 & 37.50 & 0.00 & 0.00 & 14.23 & 0.00 & 0.00 \\
\hline & & & & & $(0.00)$ & & & \\
\hline & 1.00 & 33.50 & 27.50 & 6.00 & 17.72 & 11.81 & 2.42 & 17.00 \\
\hline & & & & & $(24.78)$ & & & \\
\hline & 2.00 & 28.75 & 18.50 & 10.25 & 35.40 & 8.39 & 5.84 & 41.04 \\
\hline & & & & & $(36.45)$ & & & \\
\hline & 3.00 & 37.25 & 16.75 & 20.50 & 54.82 & 6.03 & 8.20 & 57.62 \\
\hline & & & & & $(47.78)$ & & & \\
\hline & 4.00 & 38.00 & 11.75 & 26.25 & 69.20 & 4.32 & 9.91 & 69.64 \\
\hline & & & & & $(56.32)$ & & & \\
\hline & 5.00 & 34.75 & 5.00 & 29.75 & 85.62 & 3.19 & 11.04 & 77.58 \\
\hline & & & & & $(67.76)$ & & & \\
\hline SEm \pm & - & 1.25 & 0.89 & 1.06 & 1.41 & 0.50 & 0.65 & - \\
\hline$C D$ at $5 \%$ & - & 3.71 & 2.63 & 3.16 & 4.81 & 1.47 & 1.93 & - \\
\hline
\end{tabular}

*Mean of four replications. Figures in parentheses are retransformed percent value.

Table 3: Correlation analysis of yield loss at different levels larval density of gram pod borer, $H$. armigera on different aspects during rabi 2015-16 on gram.

\begin{tabular}{|c|c|c|}
\hline Aspects & Coefficient of correlation & Regression equation \\
\hline Larval density $\times$ Total no. of pods & 0.117 & $Y=33.679+0.179 X$ \\
\hline Larval density $\times$ Healthy pods & -0.964 & $Y=32.095+-5.22 X$ \\
\hline Larval density $\times$ Damage pods & 0.985 & $Y=1.583+5.40 X$ \\
\hline Larval density $\times$ Yield per plant $(\mathrm{g})$ & -0.98 & $Y=11.957+-1.893 X$ \\
\hline Larval density $\times$ Reduction in yield & 0.98 & $Y=0.753+1.893 X$ \\
\hline Larval density $\times$ Per cent damaged pods & 0.989 & $Y=5.341+15.499 X$ \\
\hline
\end{tabular}

Table 4: Correlation analysis of yield loss at different levels larval density of gram pod borer, $H$. armigera on different aspects during rabi 2016-17 on gram.

\begin{tabular}{lcc}
\hline Aspects & Coefficient of correlation & Regression equation \\
\hline Larval density $\times$ Total no. of pods & 0.126 & $\mathrm{Y}=34.369+0.236 \mathrm{X}$ \\
Larval density $\times$ Healthy pods & -0.976 & $\mathrm{Y}=34.607+-6.043 \mathrm{X}$ \\
Larval density $\times$ Damage pods & 0.992 & $\mathrm{Y}=-0.238+6.279 \mathrm{X}$ \\
Larval density $\times$ Yield per plant $(\mathrm{g})$ & -0.986 & $\mathrm{Y}=13.711+-2.287 \mathrm{X}$ \\
Larval density $\times$ Reduction in yield & 0.986 & $\mathrm{Y}=0.519+2.287 \mathrm{X}$ \\
Larval density $\times$ Per cent damaged pods & 0.999 & $\mathrm{Y}=0.706+17.229 \mathrm{X}$ \\
\hline
\end{tabular}


caused economic damage. Sharma (1985) in a study reported the economic injury level of 1.0 larvae/m row length under artificial condition, while 2.0 larvae/m row length under natural conditions. Reddy et al (2001) also support these finding and concluded that on an average a single larva per plant reduced the yield to the extent of $138.5 \mathrm{~kg} / \mathrm{ha}$ and the EIL for $H$. armigera were determinate as 8 and 6 larvae/10 plants during the two years, respectively.

\section{CONCLUSION}

The present investigation concluded that on the basis of EIL and increase the rate of larvae, the ETL was also determine which is very helpful for control of pest and minimize the yield losses chickpea crop.

\section{REFERENCES}

Anonymous (1995). Technology for production of natural enemies. ICAR Publication pp. 75-78.

Anonymous (2016). ICAR-AICRP Chickpea Report. Project Coordinator's Report 2016-17. Annual Group Meet on Chickpea, August 28-30: 2017 pp. 36.
Hammond, R.B. and Pedigo, L.P. (1982). Determination of yield loss relationship for two soybean defoliators by using simulated insect defoliation technique. Journal of Economic Entomology. 75 (1): 102-107.

Johnston, R.L. and Bishop, G.W. (1987). Economic injury levels and economic threshold for cereal aphids on spring planted wheat. Journal of Economic Entomology. 80(2): 478-482.

Odak, S.C. and Thakar, B.C. (1975). Preliminary Studies on the Economic Threshold of Gram Pod Borer Helicoverpa armigera (Hub.) on Gram Crop. Paper presented in : All India Workshop on Rabi Pulses, APAU. Hyderabad, Sep. 29-Oct. 1: 1975.

Sharma, R. (1985). Studies on biology and extent of damage by gram pod borer Helicoverpa armigera (Hub.) M.Sc. (Unpublished) thesis, HAU, Hissar.

Reddy, C.N., Singh, Y. and Singh, V.S (2001). Economice injury level of gram pod borer Helicoverpa armigera (Hub.) on pigeonpea. Indian Journal of Entomology. 63(4): 381-387.

Vaishmpayan S.M. and Veda, O.P. (1980). Population dynamics of gram pod borer, Helicoverpa armigera (Hub.) and its outbreak situation on gram at Jabalpur. Indian Journal of Entomology. 42(3): 453-457. 